\title{
Editorial
}

\section{Lumpy Information}

\author{
$\underline{\text { Lance Gunderson }}^{1}$ and Carl Folke ${ }^{2}$
}

\section{INTRODUCTION}

Sure the poet spewed up a good lump of clotted nonsense at once.

- John Dryden

The word "lump" has many different meanings. As a noun, it can refer to a mass of indeterminate shape, or the feeling that arises on one's throat when one is overcome with emotion. Perhaps one of the first images that comes to mind at the mention of a lump is a mass on or in our bodies, not a particularly pleasant thought. One of us (Gunderson) experienced the second meaning last month during the wedding ceremony of a niece, and the other (Folke) had the same feeling the other night contemplating the beautiful midsummer sunset in the vicinity of Stockholm when a large grey seal, a species close to extinction in the Baltic Sea a few decades ago, exposed itself in calm waters feasting on a salmon. We'll leave it up to the reader to assess whether the first or third meaning refers to either of the Editors-in-Chief of this journal.

We use the word as an adjective in this editorial to refer to the amassing or packaging of information. That is the business of this journal. At first glance, the journal is not very lumpy; each article is very tailored, with the crisp boundaries of a beginning and an end and clear definitions separating one section from another. At the same time, the information content is quite lumpy, with less clarity as to shape or form. The other context for the expression "lumpy information" has to do with how information is organized across scales of time and space.

Holling (1992) introduced the word "lumps" as a way of describing the cross-scale architecture of ecosystems. What he meant was that, because of the way in which different processes influence the selforganization of complex systems across scales, the resulting structures are lumpy or clumpy. More recent developments and ideas on this subject are contained in the volume edited by Allen and Holling (2008) titled Discontinuities in Ecosystems and Other Complex Systems.

In the context of this editorial, the articles we publish occupy a certain scale range in a hierarchy of information. Part of this hierarchy is the computer you are now using to read this editorial. It too operates across a hierarchy of scales. At very small scales, invisible electrons are cycling; for example, my computer's clock cycles about 3 billion times per second. Larger but still tiny circuits called microprocessors shape the electrical signals. These processors aggregate bits to bytes to strings, all of which are lumpy, through complex instructions from programs to form the characters on the screen. These characters in turn aggregate to form the articles we publish. Over even longer time scales, these articles form a corpus of understanding. The journal is now a dozen years old, with hundreds of articles in the archives.

The articles themselves represent lumps of information that encapsulate understanding about areas and regions around the world. These articles tend to focus on understanding ecological and social dynamics over scale ranges from years to decades, and spatial scales of landscapes to regions to the globe.

\section{THIS ISSUE}

Some of the 50 articles of this issue are already organized in lumps, like the articles published as part of the special features in progress: Risk Mapp ing for Avian Influenza: a Social-Ecological Problem (Graeme Cumming, guest editor); Effects of Roads and Traffic on Wildlife Populations and Landscape Function (Rodney van der Ree, Jochen A. G. Jaeger, Edgar van der Grift, and Anthony P. Clevenger, guest editors); Pathways to Resilient 
Salmon Ecosystems (Daniel Bottom, Kim Jones, Charles Simenstad, and Courtland Smith, guest editors); Do We Need New Management Paradigms to Achieve Sustainability in Tropical Forests (Robert Nasi, guest editor); Implementing Participatory Water Management: Recent Advances in Theory, Practice, and Evaluation (Yorck von Korff, Sabine Möllenkamp, Pieter Bots, Katherine Daniell, and Rianne Bijlsma, guest editors); Catast rophic Thresholds, Perspectives, Definitions, and Applications (Robert Washington-Allen, David Briske, and Hank Shugart, guest editors); Managing Surprises in Complex Systems: Multidisciplinary Perspectives on Resilience (Lance Gunderson and Pat Longstaff, guest editors); and Historical and Fu ture Ranges of Variability (Sally Duncan and K. Norman Johnson, guest editors).

In addition, a special feature containing 12 articles, New Methods for Adaptive Water Management, is now closed. We would very much like to thank guest editors Claudia Pahl-Wostl, Jan Sendzimir, and Paul Jeffrey for their excellent work and contribution to Ecology and Society.

The remaining 27 articles can be lumped in many different ways. Here's a try.

\section{Incorporating complexity in landscape and seascape management}

Cumulative Effects of Coastal Habitat Alterations on Fishery Resources: Toward Prediction at Regional Scales. Stephen J. Jordan, Lisa M. Smith, and Janet A. Nestlerode.

Designing Landscapes for Performance Based on Emerging Principles in Landscape Ecology. Sarah Taylor Lovell and Douglas M. Johnston.

Naturalness and Place in River Rehabilitation. Kirstie Fryirs and Gary J. Brierley.

\section{Ecosystem services, values, impacts, and trade- offs}

Trade-Offs in Values Assigned to Ecological Goods and Services Associated with Different Coral Reef Management Strategies. Christina C. Hicks, Tim R. McClanahan, Joshua E. Cinner, and Jeremy M. Hills.
Consequences of Environmental Service Payments for Forest Retention and Recruitment in a Costa Rican Biological Corridor. Wayde C. Morse, Jessica L. Schedlbauer, Steven E. Sesnie, Bryan Finegan, Celia A. Harvey, Steven J. Hollenhorst, Kathleen L. Kavanagh, Dietmar Stoian, and J. D. Wulfhorst.

Enrichment Planting in Secondary Forests: a Promising Clean Development Mechanism to Increase Terrestrial Carbon Sinks. Alain Paquette, Jessica Hawryshyn, Alexandra Vyta Senikas, and Catherine Potvin.

Company-Community Logging Contracts in Amazonian Settlements: Impacts on Livelihoods and Nontraditional Forest Product Harvests. Mary C. S. Menton, Frank D. Merry, Anna Lawrence, and Nick Brown.

Selling Conservation? Scientific Legitimacy and the Commodification of Conservation Tourism. Jenny A. Cousins, James Evans, and Jon Sadler.

Ecosystem Services, Land-Cover Change, and Stakeholders: Finding a Sustainable Foothold for a Semiarid Biodiversity Hotspot. Belinda Reyers, Patrick J. O'Farrell, Richard M. Cowling, Benis N. Egoh, David C. Le Maitre, and Jan H. J. Vlok.

\section{Peoples' knowledge, natural resources, and ecosystem change}

Linking Hunter Knowledge with Forest Change to Understand Changing Deer Harvest Opportunities in Intensively Logged Landscapes. Todd J. Brinkman, Terry Chapin, Gary Kofinas, and David K. Person.

Respect for Grizzly Bears: an Aboriginal Approach for Co-existence and Resilience. Douglas A. Clark and D. Scott Slocombe.

Flavor or Forethought: Tuhoe Traditional Management Strategies for the Conservation of Kereru in New Zealand. Philip O'B. Lyver, Christopher J. Jones, and James Doherty.

Integrating Ethno-Ecological and Scientific Knowledge of Termites for Sustainable Termite Management and Human Welfare in Africa. Gudeta W. Sileshi, Philip Nyeko, Phillip O. Y. Nkunika, 
Benjamin M. Sekematte, Festus K. Akinnifesi, and Oluyede C. Ajayi.

The Problem of Scale in Indigenous Knowledge: a Perspective from Northern Australia. Marc Wohling.

\section{Approaches to adaptive management}

Application of Structured Decision Making to an Assessment of Climate Change Vulnerabilities and Adaptation Options for Sustainable Forest Management. Aynslie E. Ogden and John L. Innes.

Conceptual Models for Ecosystem Management through the Participation of Local Social Actors: the Río Cruces Wetland Conflict. Luisa E. Delgado, Victor H. Marín, Pamela Bachmann, and Marcela L. Torres-Gomez.

Reconciling Social and Biological Needs in an Endangered Ecosystem: the Palouse as a Model for Bioregional Planning. Shannon M. Donovan, Chris Looney, Thor Hanson, Yaniria Sánchez de León, J. D. Wulfhorst, Sanford D. Eigenbrode, Michael Jennings, Jodi Johnson-Maynard, and Nilsa A. Bosque Pérez.

Coastal Lagoons and Climate Change: Ecological and Social Ramifications in U.S. Atlantic and Gulf Coast Ecosystems. Abigail Anthony, Joshua Atwood, Peter August, Carrie Byron, Stanley Cobb, Cheryl Foster, Crystal Fry, Arthur Gold, Kifle Hagos, Leanna Heffner, D. Q. Kellogg, Kimberly Lellis-Dibble, James J. Opaluch, Candace Oviatt, Anna Pfeiffer-Herbert, Nicole Rohr, Leslie Smith, Tiffany Smythe, Judith Swift, and Nathan Vinhateiro.

The Role of Ecological Science in Environmental Policy Making: from a Pacification toward a Facilitation Strategy. Lucien Hanssen, Etienne Rouwette, and Marieke M. van Katwijk.

Increasing Social-Ecological Resilience by Placing Science at the Decision Table: the Role of the San Pedro Basin (Arizona) Decision-Support System Model. Aleix Serrat-Capdevila, Anne BrowningAiken, Kevin Lansey, Tim Finan, and Juan B. Valdés.

\section{Meaning, bonding, and bridging resilience}

The People Paradox: Self-Esteem Striving, Immortality Ideologies, and Human Response to Climate Change. Janis L. Dickinson

The Impact of Resource Scarcity on Bonding and Bridging Social Capital: the Case of Fishers' Information-Sharing Networks in Loreto, Baja California Sur, Mexico. Saudiel Ramirez-Sanchez and Evelyn Pinkerton

Exploring Social Resilience in Madagascar's Marine Protected Areas. Joshua Cinner, Mariana M. P. B. Fuentes, and Herilala Randriamahazo.

\section{Resilience, transformation, and innovation}

Beyond Baselines: Rethinking Priorities for Ocean Conservation. Lisa M. Campbell, Noella J. Gray, Elliott L. Hazen, and Janna M. Shackeroff.

Resilience, Adaptability, and Transformability in the Goulburn-Broken Catchment, Australia. Brian H. Walker, Nick Abel, John M. Anderies, and Paul Ryan.

Linking Resilience Theory and Diffusion of Innovations Theory to Understand the Potential for Perennials in the U.S. Corn Belt. Ryan C. Atwell, Lisa A. Schulte, and Lynne M. Westphal.

Resilience: Accounting for the Noncomputable. Stephen R. Carpenter, Carl Folke, Marten Scheffer, and Frances Westley.

In closing, we take the opportunity to thank all the people and groups responsible for producing the journal. We thank the Resilience Alliance for its commitment to and support of a high-quality, openaccess journal. We thank the subscribers for their interest and use of the material published in the journal. We again express our deepest gratitude and appreciation to the editors and reviewers who do much of the heavy lifting in producing the information lumps. Finally, the staff, Michelle Lee and Adele Mullie, who manage the day-to-day operations, and the copy editors who improve all of our writing but are rarely acknowledged. Finally, we are grateful to our contributors for their hard work and contributions to this portion of the hierarchy of information. 
Responses to this article can be read online at: http://www.ecologyandsociety.org/voll4/iss 1/art51/ responses/

\section{LITERATURE CITED}

Allen, C. R., and C. S. Holling, editors. 2008. Discontinuities in ecosystems and other complex systems. University of Columbia Press, New York, New York, USA.

Atwell, R. C., L. A. Schulte, and L. M. Westphal. 2009. Linking resilience theory and diffusion of innovations theory to understand the potential for perennials in the U.S. Corn Belt. Ecology and Society 14(1): 30. [online] URL: http://www.ecolog yandsociety.org/vol14/iss1/art30/.

Anthony, A., J. Atwood, P. August, C. Byron, S. Cobb, C. Foster, C. Fry, A. Gold, K. Hagos, L. Heffner, D. Q. Kellogg, K. Lellis-Dibble, J. J. Opaluch, C. Oviatt, A. Pfeiffer-Herbert, N. Rohr, L. Smith, T. Smythe, J. Swift, and N. Vinhateiro. 2009. Coastal lagoons and climate change: ecological and social ramifications in U.S. Atlantic and Gulf Coast ecosystems. Ecology and Society 14 (1): 8. [online] URL: http://www.ecologyandsociety. org/vol14/iss 1/art8/.

Brinkman, T. J., T. Chapin, G. Kofinas, and D. K. Person. 2009. Linking hunter knowledge with forest change to understand changing deer harvest opportunities in intensively logged landscapes. Ecology and Society 14(1): 36. [online] URL: http: //www.ecologyandsociety.org/vol14/iss1/art36/.

Campbell, L. M., N. J. Gray, E. L. Hazen, and J. M.Schakeroff. 2009. Beyond baselines: rethinking priorities for ocean conservation. Ecology and Society 14(1): 14. [online] URL: http://www.ecolog yandsociety.org/vol14/iss1/art14/.

Carpenter, S. R., C. Folke, M. Scheffer, and F. Westley. 2009. Resilience: accounting for the noncomputable. Ecology and Society 14(1): 13. [online] URL: http://www.ecologyandsociety.org/vol14/ iss1/art13/.

Cinner, J., M. M. P. B. Fuentes, and H. Randriamahazo. 2009. Exploring social resilience in Madagascar's marine protected areas. Ecology and Society 14(1): 41. [online] URL: http://www.e cologyandsociety.org/vol14/iss1/art41/.
Clark, D. A., and D. S. Slocombe. 2009. Respect for grizzly bears: an Aboriginal approach for coexistence and resilience. Ecology and Society 14(1): 42. [online] URL: http://www.ecologyandsociety.org/ vol14/iss 1/art42/.

Cousins, J. A., J. Evans, and J. Sadler. 2009. Selling conservation? Scientific legitimacy and the commodification of conservation tourism. Ecology and Society 14(1): 32. [online] URL: http://www.e cologyandsociety.org/vol14/iss1/art32/.

Dickinson, J. L. 2009. The people paradox: selfesteem striving, immortality ideologies, and human response to climate change. Ecology and Society 14 (1): 34. [online] URL: http://www.ecologyandsociety. org/vol14/iss1/art34/.

Delgado, L. E., V. H. Marín, P. L. Bachmann, and M. Torres-Gomez. 2009. Conceptual models for ecosystem management through the participation of local social actors: the Río Cruces wetland conflict. Ecology and Society 14(1): 50. [online] URL: http: //www.ecologyandsociety.org/vol14/iss1/art50/.

Donovan, S. M., C. Looney, T. Hanson, Y. Sánchez de León, J. D. Wulkhorst, S. D. Eigenbrode, M. Jennings, J. Johnson-Maynard, and N. A. Bosque Pérez. 2009. Reconciling social and biological needs in an endangered ecosystem: the Palouse as a model for bioregional planning. Ecology and Society 14(1): 9. [online] URL: http:// www.ecologyandsociety.org/vol14/iss1/art9/.

Fryirs, K., and G. J. Brierley. 2009. Naturalness and place in river rehabilitation. Ecology and Society 14(1): 20. [online] URL: http://www.ecolog yandsociety.org/vol14/iss1/art20/.

Hanssen, L., E. Rouwette, and M. M. van Katwijk. 2009. The role of ecological science in environmental policy making: from a pacification toward a facilitation strategy. Ecology and Society 14(1): 43. [online] URL: http://www.ecologyandso ciety.org/vol14/iss1/art43/.

Hicks, C. C., T. R. McClanahan, J. E. Cinner, and J. M. Hills. 2009. Trade-offs in values assigned to ecological goods and services associated with different coral reef management strategies. Ecology and Society 14(1): 10. [online] URL: http://www.e cologyandsociety.org/vol14/iss1/art10/.

Holling, C. S. 1992. Cross-scale morphology, 
geometry, and dynamics of ecosystems. Ecological Monographs 62:447-502.

Jordan, S. J., L. M. Smith, and J. A. Nestlerode. 2009. Cumulative effects of coastal habitat alterations on fishery resources: toward prediction at regional scales. Ecology and Society 14(1): 16. [online] URL: http://www.ecologyandsociety.org/vol14/ iss1/art16/.

Lovell, S. T., and D. M. Johnston. 2009. Designing landscapes for performance based on emerging principles in landscape ecology. Ecology and Society 14(1): 44. [online] URL: http://www.ecolog yandsociety.org/vol14/iss1/art44/.

Lyver, P. O’B., C. J. Jones, and J. Doherty. 2009. Flavor or forethought: Tuhoe traditioal management strategies for the conservation of kereru (Hemiphaga novaseelandiae novaeseelandiae) in New Zealand. Ecology and Society 14(1): 40. [online] URL: http://www.ecologyandsociety.org/voll4/ iss1/art40/.

Menton, M. C. S., F. D. Merry, A. Lawrence, and N. Brown. 2009. Company-community logging contracts in Amazonian settlements: impacts on livelihoods and nontraditional forest product harvests. Ecology and Society 14(1): 39. [online] URL: http://www.ecologyandsociety.org/vol14/iss1/ $\underline{\operatorname{art} 39 / .}$.

Morse, W. C., J. L. Schedlbauer, S. E. Sesnie, S. E., B. Finegan, C. A. Harvey, S. J. Hollenhorst, K. L. Kavanaugh, D. Stoian, and J. D. Wulfhorst. 2009. Consequences of environmental service payments for forest retention and recruitment in a Costa Rican biological corridor. Ecology and Society 14(1): 23. [online] URL: http://www.ecolog yandsociety.org/vol14/iss1/art23/.

Ogden, A. E., and J. L. Innes. 2009. Application of structured decision making to an assessment of climate change vulnerabilities and adaptation options for sustainable forest management. Ecology and Society 14(1): 11. [online] URL: http://www.e cologyandsociety.org/vol14/iss 1/art11/.

Paquette, A., J. Hawryshyn, A. Vyta Senikas, and C. Potvin. 2009. Envirchment planting in secondary forests: a promising clean development mechanism to increase terrestrial carbon sinks. Ecology and Society 14(1): 31. [online] URL: http: //www.ecologyandsociety.org/vol14/iss1/art31/.
Ramirez-Sanchez, S., and E. Pinkerton. 2009. The impact of resource scarcity on bonding and bridging social capital: the case of fishers' information-sharing networks in Loreto, Baja California Sur, Mexico. Ecology and Society 14(1): 22. [online] URL: http://www.ecologyandsociety.org/ vol14/iss1/art22/.

Reyers, B., P. J. O'Farrell, R. M. Cowling, B. N. Egoh, D. C. Le Maitre, and J. H. J. Vlok. 2009. Ecosystem services, land-cover change, and stakeholders: finding a sustainable foothold for a semiarid biodiversity hotspot. Ecology and Society 14(1): 38. [online] URL: http://www.ecologyandso ciety.org/vol14/iss1/art38/.

Serrat-Capdevilla, A., A. Browning-Aiken, K. Lansey, T. Finan, and J. B. Valdés. 2009. Increasing social-ecological resilience by placing science at the decision table: the role of the San Pedro Basin (Arizona) decision-support system model. Ecology and Society 14(1): 37. [online] URL: http://www.ecologyandsociety.org/vol14/iss 1/ $\underline{\operatorname{art} 37 /}$.

Sileshi, G. W., P. Nyeko, P. O. Y. Nkunika, B. M. Sekematte, F. K. Akinnifesi, and O. C. Ajayi. 2009. Integrating ethno-ecological and scientific knowledge of termites for sustainable termite management and human welfare in Africa. Ecology and Society 14(1): 48. [online] URL: http://www.e cologyandsociety.org/vol14/iss1/art48/.

Walker, B. H., N. Abel, J. M. Anderies, and P. Ryan. 2009. Reslience, adaptability, and transformability in the Goulburn-Broken Catchment, Australia. Ecology and Society 14(1): 12. [online] URL: http://www.ecologyandsociety.org/vol14/iss 1/ $\underline{\operatorname{art12}}$.

Wohling, M. 2009. The problem of scale in indigenous knowledge: a perspective from northern Australia. Ecology and Society 14(1): 1. [online] URL: http://www.ecologyandsociety.org/vol14/iss1/ art1/. 